International Journal of Advanced Academic Research | ISSN: 2488-9849

Vol. 7, Issue 3 (March, 2021) |www.ijaar.org

Journal DOI: www.doi.org/10.46654/ij.24889849

Article DOI: www.doi.org/10.46654/ij.24889849.s7314

\title{
THE EFFECT OF VALUE CO-CREATION ON CUSTOMER RETENTION IN AVIATION INDUSTRY IN NIGERIA
}

\author{
Worlu, Stanley Dike \\ Department of Marketing, University of Port Harcourt, Choba, Port Harcourt \\ hachikaruikechi@gmail.com \\ Sunny, R. Igwe, Ph.D \\ Department of Marketing, University of Port Harcourt, Choba, Port Harcourt \\ Email: chikordi@yahoo.com
}

\begin{abstract}
The study examined the effect of value co-creation on customer retention in Aviation Industry in Nigeria. Customers are becoming more apprehensive of firms they are satisfied and want to always be part of their value co-creation and satisfaction. A sample size of 303 customers and employees were surveyed through questionnaire. The data were analyzed using regression analysis which was facilitated by the application of Statistical Package for Social Science (SPSS Version 23.0). The study found a significant relationship between value cocreation and customer retention in Aviation Industry in Nigeria. Hence, the study concluded that value co-creation affects customer retention thus, recommended that Management should retain customers who develop customer citizenship as this will increase customer retention in Aviation Industry in Nigeria. Management should pursue customer retention strategies by engaging and involving customers in strategic activities that will lead to quality business transaction to increase emotive commitment in Aviation Industry in Nigeria.
\end{abstract}

Keywords: Value Co-Creation, Customer Retention, Customer Citizenship, Referrals, Repeat Purchase. 


\section{Introduction}

The aim of most marketing activities until the 1990s was to attract new customers, although retention was also listed, as it was already necessary to maintain existing customers. The rationale for this reasoning is based on the understanding that long-term consumers compare deals and select the ones that seem to fit their needs better (Hundre, Kumar \& Kumar, 2013).Consumers are now more and better educated through the growth of the internet. Consumer retention is important in all economic sectors, however, poor level of customer retention is an indication that consumers perceive a decline in the value stream of the business (Jones \& Sasser, 1995). What is assured is that existing customers can buy more in the long run, consume less time from the business because they are familiar with the goods and services. They are also less price sensitive and refer new customers (Reichheld, 1996). The awareness and mapping of the causes of consumer exit thus emerges as a way for organizations to recognize weaknesses and practices.

Today, firms are focusing on persuading and attracting customers in the spirit of seeking growth and profit maximization by putting up activities that keep existing customers and attract potential customers to the business. The competitive nature of today's business world has made firms to design strategies and operational techniques for sustenance of existing customers (Ang \& Buttle, 2005). To achieve customer retention effectively, the Industry need to devise strategies to retain customers. Therefore, retention of customers in a densely competitive Industry requires the satisfaction of market requirements (Egan, 2004).

Before customers can be retained they need to develop the feelings of pleasure after consuming products or services by a firm (Oliver, 2006). This pleasure or satisfaction is attained after the performance of the product or services is compared with the expectations or what they had in mind before consumption (Oliver, 2006). When customers are satisfied, they develop retention which enhances growth and development of the Industry thereby increases volume of sales and profit realizations (Oliver, 2006). Additionally, the Industry will progress and will see customer retention as a goal and seek ways to retain it in order to continue in business operation. However, one of the vital means of achieving customer retention is through value co-creation of products and services.

As promoted by Ramaswamy and Gouillart (2010), any organization that seeks to remain or be sustained in business and striving towards achieving competitive advantage over its competitors must device a new strategy or plan on how value will be created for customer's satisfaction. Value co-creation is a paradigm or strategy to achieve customer retention. Therefore, the study developed two dimensions of value co-creation which were used to access the extent to which customers can be retained. The two dimensions include: customer citizenship and engagement involvement (Ramaswamy \& Gouillart, 2010).

Customer citizenship is a voluntary behaviour of a customer to favour the organization. The customer display or show this kind of behaviour to attract potential customers and encourage them to buy the firm's products. Customer citizenship behaviour is an extra-ordinary behavior exhibited discretionally by a customer having been satisfied after consumption of the firm's services and product. When customer citizenship behavior is noticed, the firm can allow such customer to be part of value co-creation because such customer can make meaningful contributions to value co-creation initiatives (Srinivasan \& Hanssens, 2009). 
Another important dimension is engagement involvement: A situation where the organization engages a customer and involves the customer in value co-creation activities. It is an opportunity given to customers by an organization to jointly create value according to their wants and needs. Customers are engaged by the firm after their behaviors have been studied that they can make meaningful contributions. Although scholars have examined value cocreation over the years (Ramaswamy \& Goüllart, 2010; Spreng, Harrell and Mackoy, 1995) but linking value co-creation with customer retention, referrals and repeat purchase have not being widely studied in literature. This lack of empirical studies on value co-creation and customer retention might have affected the extent to which management perceived value cocreation which supposed to serve as a strategy for retaining customers. The identification of the determinants customer retention and its implications for business is important in order to know the reasons why customers break the relationship totally or partially with their main company, and how co-creation can assist management to attract new customers as well as retain older ones justifying the importance of this study (Reichheld, Markey \& Hopton, 2000). Thus, the present study filled this knowledge gap as it studied value co creation and customer retention in Aviation Industry in Nigeria.

\section{Statement of the Problem}

In Nigeria, the demand for air transport services has been on the increase within the past three decades. There has been growth in passenger, aircraft and freight traffic as a result of physical and economic development of cities in different parts of the country. Failure of the industry to produce quality goods and services inevitably led to customer defection which is the opposite of customer retention (Kau \& Loh, 2006). Customer defection is an enlightening measure in business. First, it is the sign that customers are detecting deterioration in the company's value stream. Second, exit can be a sign of a declining flow of money from customers to the company, even if it replaces lost customers (Reichheld \& Sasser, 1989).

Lack of customer retention is noted in regular complaints by customers over the years. This shows that customers are moving from one firm to the other. Instead of travelling by Air, more are traveling by road and water ways. This shows a high defection rate in the Aviation industry. Therefore, Aviation Industry need to be just as good at winning new customers in addition to increasing their income as they keep the customers they have already won. Studies pointed out that those businesses can avoid lost by preventing even minor defection from customers to rivals (Ramakrishnan, 2006).

Why customers are not retained might be traced lack of engagement involvement and customer citizenship. Additionally, the use of obsolete equipment and poor infrastructure; low quality products and poor services by the Aviation industry also led to customer dissatisfaction and intention to leave. The manifestations of poor customer retention have affected the growth, sales volume, and profitability of Aviation Industry in Nigeria. Hence, as the industry serves an important purpose in the economic development in Nigeria, their poor performance will also cause poor economic performance in the country. Thus, the justification of the present study is to examine the relationship between value co-creation and customer retention in Aviation Industry in Nigeria with aim to provide solution to this problem. Furthermore, this type of problem was experienced in Aviation Industry in the foreign environment and PRACTICE theory were found effective in providing solution to such problem. Hence, the present study uses PRACTICE theory in providing solution on how value co-creation can be used to improve customer retention in Aviation Industry in Nigeria. 


\section{Aim and Objective of the Study}

The aim of this study is to examine the effect of value co-creation on customer satisfaction in Aviation Industry in Nigeria, while the study objectives are:

\section{Research Questions}

The following research questions guide the study

1. How does customer citizenship affect referrals in Aviation Industry in Nigeria?

2. In what ways does customer citizenship affect repeat purchase in Aviation Industry in Nigeria?

3. What is the effect of engagement involvement on referrals in Aviation Industry in Nigeria?

4. In what way does engagement involvement affect customer repeat purchase in Aviation Industry in Nigeria?

\section{Research Hypotheses}

The following research hypotheses were formed to guide the study:

Ho 1 : Customer citizenship does not have any significant effect on customer referrals in Aviation Industry in Nigeria.

Ho$_{2}$ : Engagement involvement has no effect on customer repeat purchase in Aviation Industry in Nigeria.

Ho3: Engagement involvement has no effect on customer referrals in Aviation Industry in Nigeria.

Ho4: Engagement involvement has no effect on customer repeat purchase in Aviation Industry in Nigeria.

\section{Scope of the Study}

The study was domiciled in relationship marketing and consumer behaviour because value co-creation emphasizes on establishing cordial relationship with customers with the aim of attracting and retaining customers. The geographical scope covered all Airline firms in Nigeria.

The unit/level of analysis was ascertained from the individual level because the study considered on customers of the Aviation industry. Additionally, these categories of respondents are direct consumers of products and services offered by this industry.

\section{Significance of the study}

The study examined the effect of value co-creation on customer retention in Aviation Industry. This study will generate practical benefits to Aviation industry on the concept of value co-creation and customer retention. The study will assist Aviation and Airline management to revitalize the importance of value co-creation process as technique for retaining customers in order to improve the performance of Aviation industry in Nigeria. This study will increase the volume of research studies on value co-creation and customer 
satisfaction in literature. Scholars will also use the findings of this research work as a foundation for future research through identification of knowledge gap.

\section{LITERATURE REVIEW}

\section{Theoretical Framework}

This study adopted Practice Theory by Duguid (2005) which explained how value co-creation works. Practice theory explains that each time two or more people practice a common thing together, both parties' stand to benefit from their shared opinion (Duguid, 2005). This theory is important to value co-creation in this context because it involves customers and the firm to jointly decide on how service quality would be created for the benefit of both parties but most especially to the customers. When customers are satisfied, the organization will grow and will experience increase in sales volume and becomes profitable (Frow \& Payne, 2013; Frow, Nenonen, Payne \& Storbacka, 2015). Practice theory also explains that customers and the firm must come together to discuss the value of services to be delivered. When customers and firm come together they must interact, and this interaction will lead to friendliness, mutual understanding, trust for both parties etc. Duguid (2005) posited that firms usually welcome ideas generated by customers because the production of goods and services are for the customers. Practice theory supports value co-creation and it encourages firms to practice it at all times. From the idea of Practice-Theory, customers tend to be the most influencing factor in the process of value co-creation. During this process, firms seek ideas from customers with the aim to improve business performance. Practices serves as background in copying skills which actors consciously develop in order to solve everyday life challenges (Warde, 2005; Orlikowski, 2007; Schatski, 2006).

In conclusion, Practice Theory strengthen customers' perception and fortify the role they play in decision making which makes customers to act as partial employees of the organization Accordingly, firms need to adopt Practice Theory because it provides an opportunity to both customers and employees of an organization to copy relevant skills and enhances each other's view point on the values of products and services. Therefore, customers' interaction with the firm becomes the key factor in the Practice Theory. Thus, firms that apply Practice Theory in its operations will retain huge number of customers than others.

\section{Empirical Review}

Empirical review involves reexamining the studies by previous researchers in order to identify the tools used and what they find from their study compare such to the present findings to make valid conclusion and recommendations. Yi and Gong (2013) have approached value co-creation and found two types of behaviours; the participating behavior and Citizenship behavior. The participating behaviours related to one's 'in-role behaviors while the other one (citizenship behavior) is extra-role behavior. Participation behavior which is in other words called an (in-roll) behavior is when a customer is engaged to participate in value co-creation to achieve the success of value co-creation. While citizenship behavior is in other words called extra-role behavior of a customer which does not necessarily lead to the success of value co-creation (Groth, 2005; Bove, Pervan, Beatty \&Skiu, 2009; Yi Nataijam \& Gong, 2011). The above authors stated that participation behavior (in-role) and customer citizenship (extra-role) behavior are not the same. Each of them produced different results 
because each of them has different antecedents or consequences (Growth, 2005; Yi, Natarajin \& Gong, 2011).

Yi and Gong (2013) also conceptualized participation behavior and customer citizenship into parts that constitutes multiple dimensions. For instance the participation behavior: consists of Information seeking behavior, information sharing behavior, responsible behavior, and personal interaction, while, customer citizenship behavior consists of providing feedback, advocacy, helping and tolerance. These dimensions have exerted great influence on the firm and its customers. Customers and the firm will benefit from value co-creation practice in terms of increase in sales volume, increase in organizational performance, increase in growth and profitability by the organization or the Aviation Industry and satisfaction on the part of customers.

Maduka (2016) studied customer loyalty in the Nigerian Service Industry with respect to the effects of customer value co-creation. The aim of the research was to see how customer value co-creation affects customer loyalty in the service industry, and IBTC pension was used to represent the Nigerian service industry. Firms used to design products, produce products, build marketing messages, and so forth on their own, with hardly any involvement from or interaction with consumers. In any aspect of the business environment, consumers now want to exert their power. This has contributed to the imminent query, "should consumers be involved in service formation to keep them satisfied"? The DART Model elements (Dialogue, Access, Risk Assessment and transparency) were adopted in order to assess customer satisfaction in the pensions industry in Nigeria. The research adopted the method of survey design conducted among individual IBTC pension employees and customers. To produce data for the analysis, a standardized questionnaire was used. To test the hypotheses developed for the analysis, Multiple Regression was used. The findings show that there is indeed a positive and significant impact of co-creating services on customer loyalty, notably in the pension industry in Nigeria, as Nigerian customers want to be certainly part of the services provided. As a result, it is expected that the results of this study will provide guidance to service industry managers about the importance of involving customers in the development of value in order to keep them informed about organizational success and thereby make them loyal customers, as well as serve as a guide to potential new entrants in the industry about better ways to deliver services in order to get the better off competition.

Nedra Bahri Ammari and Emna Jaziri (2016) examine how co-creating enhances the quality of a brand-consumer relationship, using the U\&G approach and Coca-Cola as a Case study. They assess the driving factors that lead to a consumer participating in a co-creation operation, with a focus on the effect of engagement on customer retention. The study approaches a sample size of 360 respondents. As a result, the research presented a new U \& $\mathrm{G}$ approach to the principle of joint value production. A questionnaire was created and circulated through Google Drive to consumers and users of the Coca-Cola proposed application's Chnia Tarbijtek. A structural equation (SEM) with AMOS was used to evaluate the hypothesis after 360 questionnaires were done. The findings reveal that social and personal integration has a positive impact on online co-creation, while learning has the reverse effect. Co-creation has a positive impact on the strength of the partnership, confidence, and happiness of both customers and users.

Using a Service-Dominant logic, this study examines the relationship between value cocreation activity, perceived service efficiency, consumer happiness, and customer loyalty. 
Theoretical basis for (SD logic): Making use of structural equations, the research looks at a selection of 350 online products in Indonesian groups. The results of the analytical study show that value co-creation behaviour has an effect on perceived service efficiency and consumer loyalty. It also indicates that customer retention and perceived service efficiency have an effect on customer loyalty. Customers must be motivated to engage in the value cocreation process for it to be successful. However, from past studies reviewed, it is clear that value co-creation improves customer retention. Although, these studies were conducted in the foreign environment with different culture managerial styles which may not exactly be what is obtained in the domestic environment like Nigeria. Thus, it is expected value co-creation will also improve customer retention in Nigeria.

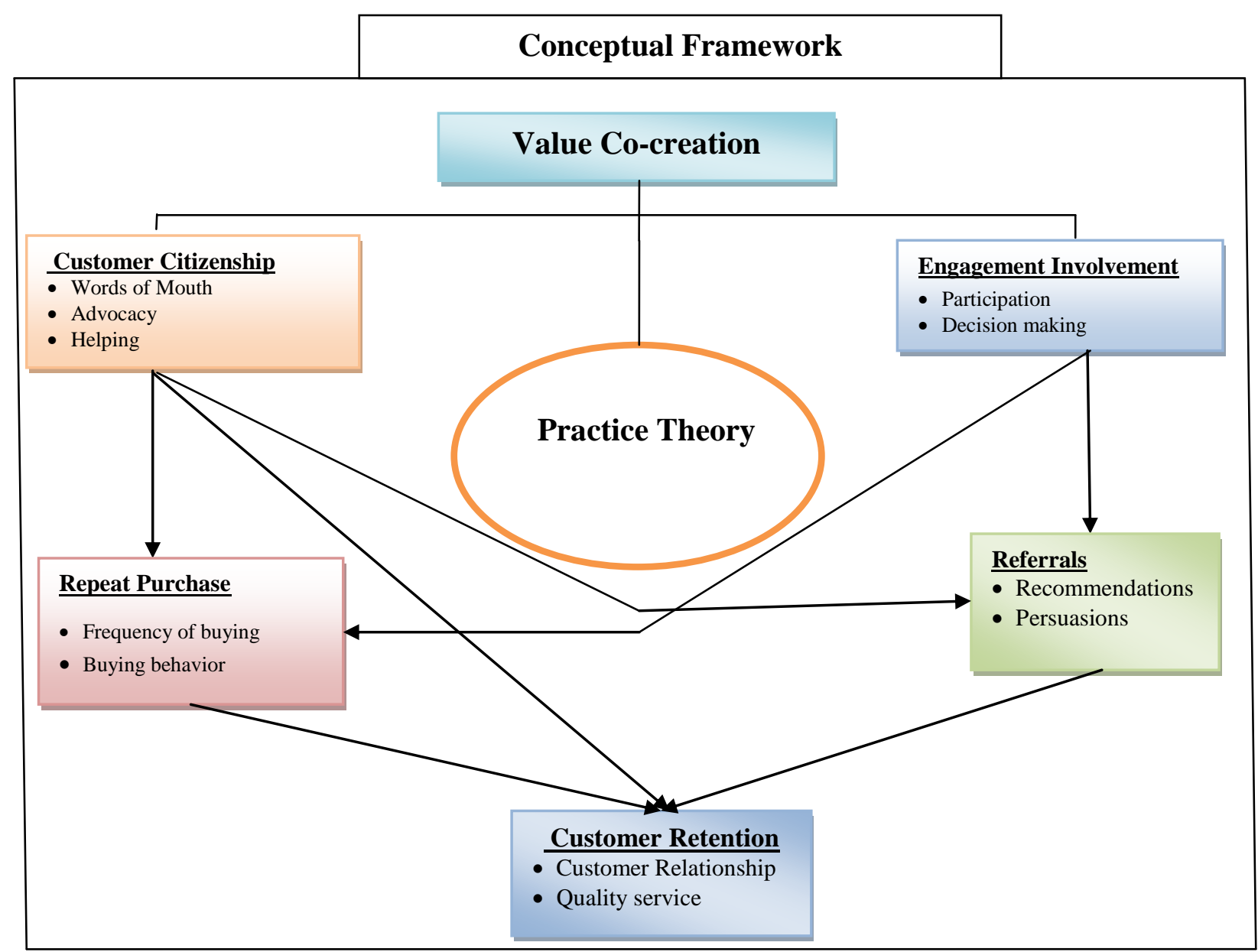

Source: Dimensions of Value Co-Creation (Spreng, Harrell \& Mackoy, 1995; Nirmali, et al., 2001; Ramaswamy \& Ozcan, 2014). Measures of customer retention (Gronroos, 2000).

\section{Value Co-Creation}

Value is that benefit which a customer experienced or feels in his cognitive thinking derived after consuming a product or service. The benefit derived could be seen when he thinks about the product mentally (cognitively) or see it physically. The value of a product or service comprises of the size, quantity, taste, durability, cost, design (package) duration and time of delivery (Kotler \& Keller, 2009). Gronroos (2008) explained the detail meaning of value co- 
creation by providing three basic elements of value co-creation activities. The three basic elements are customer sphere, supply sphere and joint sphere. Customer sphere means that value co-creation is reached by involving customers in creating the value that will benefit the customers, to the organization and other potential customers who were not privileged to participate in the co-creation process. When customers participate in deciding the value, it then means both parties are responsible for what will be of common interest for the parties.

\section{Customer Citizenship Behavior}

This is an extra ordinary behavior or role which a customer displays voluntarily without payment or reward. The customer is a citizen of the firm as he encourages others to patronize the firm. The customer was not commanded by the organization to demonstrate such behavior (Bove et al., 2009). Bove et al. (2009) claimed that citizenship behavior is a behavior which a customer chooses to exhibit. For instance, he may choose to be helping intending customers on how to handle the goods and services provided by a firm (Groth, 2005). In other words such voluntary helping behavior and customer voluntary performance adds to the firm's meaningful operations and image improvement (Bettercourt, 1997). The firm or Airline did not promise to give him anything for demonstrating customer citizenship behavior but customer demonstrating this behaviour is seen using word of mouth to convince other potential customers to patronize the products of the Airline and services because he was satisfied with the goods and services provided by the Airline on different occasions The customer shows tolerance on the firm's offering, provide voluntary service and feedback and supports (Yi \& Gong, 2013). He displayed such customer citizenship behaviour to enhance the organization and its performance efficiently and effectively (Groth, 2005).

\section{Engagement Involvement}

Engagement involvement entails the strategic way of allowing customers to participate in organizations' decision making in guiding what business does or operation (Anaza \& Zhao, 2013). Engagement involvement means allowing customers' Participation and involvement in decision making. In this way, engagement involvement focus on practical issues of making contact with customers to raise awareness and to spur them to offer jobs, work placements and other employment-related opportunities. It can also take place on a relatively informal basis, without putting any 'good practice' requirements on employers (beyond meeting legal obligations). Some partnerships have sought to institute charters and other good practice principles that are in-line with the business ethics through engagement involvement (Chu \& Kim, 2011). A single customer may be involved in more than one way and at different times (Song \& Carl, 1993). Engagement involvement is also seen as a vehicle that facilitates customer retention by the organization (Anaza \& Zhao, 2015). Engagement involvement enables customers to know the deep things in the organization and afford them the chance to make contributions that assist management in their operation. Engagement involvement yield benefits to customers as they learn new things from the firm and develop loyalty to the firm. It is also very easy for an organization to engaged and involve customers when both parties are in need of information which will also help in developing brand loyalty by customers. Therefore, engagement involvement will improve customer retention in Aviation Industry in Nigeria.

\section{Customers Retention}

Today, firms are focusing on persuading and attracting customers. Hence, firms in the spirit 
of seeking growth and profit maximization put up activities that keep existing customers and attract potential customers to remain in business operations (Ang \& Buttle, 2005). Retention of customers in a densely competitive Industry requires the satisfaction of market requirements (Egan, 2004). Ramakrishnan (2006) stated that customer retention prevent customers not to switch over to competitors. Buttle (2008) opined that customer retention is equal to the total number of customers in business with the firm from the beginning of its accounting year expressed as a percentage of those that were active at the beginning of the year to the end of that accounting period.

Customer retention is customer's share that maintained business partnership with a firm for a defined period, say one year or more. Customer retention influence revenue and cost in equation probability. It is fitting to state that customer retention and its strategies are conscious efforts by organizations to retain current buyers and to remain competitive in business operations (Gupta \& Lehmann, 2003). Customers are also drawn due to customer relationship and quality service to the form. Thus, when an industry like Aviation have in mind to retain its customers it does this in order to withstand the turbulent business challenges and gain competitive advantage (Vilare et al., 2001) in the market.

\section{Referrals}

Referrals is the process of recommending and persuading potential customers to the firm' products and services. With referrals, is satisfied customer is asked to provide the names of others who might be integrated in a product. In some cases the person may also supply an introduction of the sales-person to the prospects. The advantage of referrals is that the person can say things about the sales person (Jolson \& Wotruba, 1997). One residential protection agency uses interesting referrals technique. The company holds a walkthrough party after completing an alarm system installation. The customer is encouraged to invite as many as four neighbours or friends to observe the well-organized walkthrough party in the use of the system (Jolson \& Wotruba, 1997). Therefore, the company added more customers to the existing ones through this method.

Referrals increase engagement and involvement; it makes brand awareness to be spread and serves as technique to gain loyal customers. It was found that customers are $4 \mathrm{x}$ more likely to buy when referred by a friend. The lifetime value of referred customers was estimated to be $16 \%$ higher, on average, than that of non-referred customers. Thus, with this simple example in mind, Aviation industry in Nigeria can gain more customers through the encouragement given to customers on referrals.

\section{Repeat Purchase}

Repeat purchase is one the measures of customer retention because it is the customer that decides whether to repurchase the products or services. First of all, the customer will review the brand experience developed during product or service usage and then, decide on it. Their decision is based on how satisfied they are with the products or services (Kotter \& Armstrong, 2016). In recent times, firms begin to develop more interest in repeat purchase behavior of customers because such behavior not only make the firm to gain competitive advantage and sustain it but helps the firms to increase reverence and profits under the competitive business environment. A firm that seeks repeat purchase decreases costs associates with getting new customers (Kuo, Huo, Hu \& Yang, 2013: Reicheld \& Sasser, 
1990). For instance, Reichheld and Sasser (1990) found that the profit made by a firm can increase from $25 \%$ to $85 \%$ with just $5 \%$ increase in retaining existing customers. On the opposite side, the firm can spend 5 times increase cost just to get new customers. Jones and Sasser (1995) argue that customers in general derived satisfaction from a product or service and that is what made them to repeat purchase. Therefore, the importance of repeat purchase cannot be overemphasized. Since this study focused on value co-creation and customer retention, repeat purchase of customers in Aviation Industry will add more values to sales volume and growth of the industry.

\section{METHOD}

A cross sectional survey design was adopted. The cross sectional survey research design relies on a sample of elements from the population of interest which are measured at a single point in time. Finally, it involves using questionnaire in drawing response on the variables under investigation (Baridam, 2001). The target population comprises of customers (internal/external customers) in Aviation Industry in Nigeria. The available record indicates eight (8) operational Airline services in Aviation industry in Nigeria within the research period. These Airlines have their branches in Port Harcourt International Airport (Industry Report, 2019). However, the study examined 1600 respondents comprised of internal and external customers in the eight (8) operational Airline Services. This accessible population of 1600 respondents was determine from the human resource department of each Airline using purposive or convenient sampling technique.

The study adopted Taro Yamane's sampling technique (Yamane, 1967). This technique helps in determining the sample size of 320 customers from huge population of 1600 respondents. Furthermore, Bowley (1964)'s technique was applied for the purpose of adequate distribution of questionnaire. The instrument was entitled "Value Co-Creation and Customer retention Questionnaire" (VCCCRQ). The instrument consisted of nineteen (19) items which sought the views of respondents on value co-creation and customer retention in the Aviation Industry in Nigeria. The demographic data were obtained directly from the customers on age of respondents through questionnaire on educational qualifications, experience, and the frequency of travel with the Aviation Industry. The data for the variables were also gathered from respondents through questionnaire which captured customers' opinion expressed to the items on the study variables.

\section{Operational Measurement of Variables}

The predictor variable is value co-creation and its dimensions are customer citizenship and engagement involvement, while the criterion variable is customer retention and it measures is referrals and repeat purchase.

Customer Citizenship: Five item statements by Smith et al. (1983) and Rosenbaum and Massiah (2007) were used in measuring this variable on a Likert 5-point scale. The response mode ranged from 1-5 points and score of 1 was assigned to Neutral; $2=$ strongly disagree' $3=$ disagree; 4=agree; and 5= strongly agree. Sample items are: I willingly give feedback to my airline on ideas that will improve services to customers; I extend empathy to other customers through helping behavior with respect to car hiring services and theft of luggage; encouraging others to develop tolerance towards service failures in my airline is important to me; 1 willingly alert my airline and other customers on security and safety threats. Advocating the services of my airline to others is my concern. 
Engagement Involvement: Five item statements by Andrews et al. (1990) were used in measuring this variable on a Likert 5-point scale. The response mode ranged from 1-5 points and score of 1 was assigned to Neutral; 2=strongly disagree' $3=$ disagree; 4=agree; and $5=$ strongly agree. Sample item are: My Airline normally invites me to participate in their meetings to create knowledge on quality services; My Airline allows me to make suggestions to improve service delivery; My Airline always involve me in their decision making process on Car Hiring Service creation and regulations; My Airline involves me in decision making process on Runways and Lighting Points to meet customers' needs; My Airline allows me to participate in information search on quality services

The criterion variable is customer retention with its measures; referrals and repeat purchase.

Referrals: Four item statements by Gengeswari, Padmashantini and Sharmeela (2013) were modified and were used in measuring this variable on a Likert 5-point scale. The response mode ranged from 1-5 points and score of 1 was assigned to Neutral; $2=$ strongly disagree' $3=$ disagree; 4=agree; and 5= strongly agree. Sample item are: $i$ express positive word of mouth (wom); I often recommend this airline; I share information about this airline; I volunteer as spokesperson for this airline; I prefer suggesting this airline to others.

Repeat purchase: Four item statements by Gengeswari, Padmashantini and Sharmeela (2013) were modified and used in measuring this variable on a Likert 5-point scale. The response mode ranged from 1-5 points and score of 1 was assigned to Neutral; $2=$ strongly disagree' $3=$ disagree; $4=$ agree; and 5= strongly agree. Sample item are: I do not prefer other Airline; I delighted to shop at this Airline; I shop at regular price in this Airline.

\section{Validity and Reliability of Instrument}

This section of the study examined the validity and reliability of the instrument because wrong choice of inappropriate validity and reliability test may affect the research in gathering the required and appropriate data. The study adopted face and content validity, hence, the instrument was subjected to scrutiny by supervisors and other experts and was found that the item statements properly represent the variables measured (face validity) Content validity was ascertained using multiple items that cover all aspect of the variables (Spector, 2008). This shows that the domain of all variables was covered with items necessary for the measurement.

The study applied Cronbach Alpha reliability test as the instruments to achieve reliability and the score of 0.7 or above was the benchmark for reliability acceptance (Cronbach, 1951). The reliability test computation was performed through the application of SPSS version 23.0. Thus, the following results were obtained. Customer citizenship scored $0.861 ; \mathrm{n}=5$ : engagement involvement scored $0.865 ; \mathrm{n}=5$ : referrals scored $0.773 ; \mathrm{n}-5$ : repeat purchase scored $0.898 ; \mathrm{n}=4$. Thus, from the result, it shows reliability score above 0.7 was attained, meaning that the instrument was reliable. We examined our topic and the statement of hypotheses and chose the appropriate inferential statistic to analyze our data. We used descriptive and inferential statistics in our data analysis. The tools for descriptive data analysis were; percentages, the mean and standard deviation (SD). The inferential statistic focuses on testing the hypotheses using Regression Analysis. 


\section{RESULTS AND DISCUSSION}

The useful and abandoned copies of questionnaire were recorded and displayed on tables. Table 4.1 shows the analysis of questionnaire issued and the percentage of copies retrieved were used in our analyses. A total of 320(100\%) copies of questionnaire were administered to the eight (8) Aviation Firms. The obtained useful copies were 303(94.7\%). This result indicates that huge number of the respondents participated in providing data for this study. This shows a success in questionnaire administrations.

Table 1. Demographic (Descriptive) Data Analysis

\begin{tabular}{|c|c|c|}
\hline Gender & Response Rates & Percentage $(\%)$ \\
\hline Male & 156 & 51.5 \\
\hline Female & 147 & 48.5 \\
\hline Total & 303 & $100 \%$ \\
\hline Age of the Respondents & Response Rates & Percentage (\%) \\
\hline $20-30$ years & 54 & 17.8 \\
\hline $31-40$ years & 76 & 25.1 \\
\hline $41-50$ years & 137 & 45.2 \\
\hline Above 50 years & 36 & 11.9 \\
\hline Total & 303 & $100 \%$ \\
\hline Educational Qualification & Response Rates & Percentage $(\%)$ \\
\hline O' Level & 49 & 16.2 \\
\hline OND/NCE & 47 & 13.5 \\
\hline DEGREE/HND & 133 & 43.9 \\
\hline M.Sc/MBA & 40 & 13.2 \\
\hline Ph.D/DBA & 34 & 11.2 \\
\hline Total & 303 & $100 \%$ \\
\hline Years of Experience & Response Rates & Percentage (\%) \\
\hline $0-5$ years & 56 & 18.5 \\
\hline $5-10$ years & 128 & 42.2 \\
\hline $10-15$ years & 81 & 26.8 \\
\hline 15- years and above & 38 & 12.5 \\
\hline Total & 303 & $100 \%$ \\
\hline
\end{tabular}


The result on table 1 showed that 156 of the respondents indicated as male, while 147 were female. This show a good gender mix equally responded. From the age of respondents, 4.3, $54(17.8 \%)$ were between $20-30$ years, $76(25.1 \%)$ were between $31-40$ years, while 137 (45.2\%) were between $41-50$ years and only $36(11.9 \%)$ were above 50 years. The evidence of the result indicates that majority were 41-50 years.

From table 4.4, 49(16.2\%) were O' Level certificate holders, 47(13.5\%) were OND/NCE certificates holders; while, 133(43.9\%) were BSc/HND degree holders, while 40(13.2\%) were M.Sc/MBA degree and only 34(11.2\%) were Ph.D/DBA degree holders. Thus, from the result, high percentages were Degree/HND educational qualifications.

The result on table 4.5 with respect to respondents years of experience shows that $56(18.5 \%)$ were between $0-5$ years; $128(42.2 \%)$ were between 5 -10 years; $81(26.8 \%)$ were between 10 15 years and $38(12.5 \%)$ were 15 years and above. This result shows that huge respondents indicated between 5-10 years

\section{Univariate analysis}

In this section the variables were measured on Likert's 5-point scale through the items on the questionnaire. The benchmark for acceptance was based on the mean score of items on Likert scale 5-point scale. The mean score of 3.00 was the acceptable mean and was derived from the following computation;

Criterion mean $=\frac{1+2+3+4+5}{5}=3.00$

This implies that only response rate to items that meet the criterion mean of 3.00 or above were accepted.

Table 2. Results of univariate analysis of the study variables

Item Statistics

\begin{tabular}{|l|l|l|l|}
\hline Variables & Mean & $\begin{array}{l}\text { Std. } \\
\text { Deviation }\end{array}$ & $\mathbf{N}$ \\
\hline Customer Citizenship & 3.8376 & .98524 & 303 \\
\hline Engagement involvement & 3.8917 & 1.11853 & 303 \\
\hline Referrals & 3.8632 & .95234 & 303 \\
\hline Repeat purchase & 3.7949 & .81281 & 303 \\
\hline
\end{tabular}

Source: SPSS Output (2021)

The result on univariate analysis of the study variables shows that the mean score of the items are above 3.00 which is the benchmark mean. This implies that majority of the respondents provided answers and agreed to the items on these variables.

\section{Regression Analysis}

The study tested the effect of value co-creation on customer satisfaction. A regression analysis enabled the study to determine the overall fit (variance explained) of the model and the relative contribution of each of the predictors to the total variance explained in criterion variable. Additionally, regression analysis makes us to understand whether customer retention can be predicted based on customer citizenship and engagement involvement. 
Table 3. Model Summary Result with respect to Referrals

Model Summary

\begin{tabular}{|c|c|c|c|c|c|c|c|c|c|}
\hline \multirow[b]{2}{*}{$\begin{array}{l}\text { Mod } \\
\text { el }\end{array}$} & \multirow[b]{2}{*}{$\mathrm{R}$} & \multirow[b]{2}{*}{$\begin{array}{c}\mathrm{R} \\
\text { Square }\end{array}$} & \multirow[b]{2}{*}{$\begin{array}{l}\text { Adjusted R } \\
\text { Square }\end{array}$} & \multirow[b]{2}{*}{$\begin{array}{l}\text { Std. Error } \\
\text { of the } \\
\text { Estimate }\end{array}$} & \multicolumn{5}{|c|}{ Change Statistics } \\
\hline & & & & & $\begin{array}{c}\text { R Square } \\
\text { Change }\end{array}$ & $\begin{array}{c}\mathrm{F} \\
\text { Change }\end{array}$ & df1 & df2 & $\begin{array}{c}\text { Sig. F } \\
\text { Change }\end{array}$ \\
\hline 1 & $.931^{\mathrm{a}}$ & .866 & .864 & 1.659 & .866 & 480.937 & 4 & 298 & .000 \\
\hline
\end{tabular}

The value of 0.931 indicates a good level of prediction. The "R Square" of 0.866 is the $R^{2}$ value which is the fraction of variance in the customer referrals that can be explained by customer citizenship and engagement involvement. Hence, from the result, $14 \%(100 \%-$ $87 \%$ ) of the variation is caused by factors other than the predictors in this model. Thus, $87 \%$ proportion of variance in the referrals can be explained by customer citizenship and engagement involvement.

\section{(i) Statistical Significance of the Model:}

\section{Table 4. ANOVA Result}

\begin{tabular}{|ll|r|r|r|r|r|}
\hline Model & & Sum of Squares & \multicolumn{1}{|c|}{ df } & Mean Square & \multicolumn{1}{c|}{ F } & Sig. \\
\hline 1 & Regression & 5295.104 & 4 & 1323.776 & 480.937 & $.000^{\circ}$ \\
& Residual & 820.243 & 298 & 2.752 & & \\
& Total & 6115.347 & 302 & & & \\
\hline
\end{tabular}

a. Dependent Variable: Referrals

b. Predictors: (Constant), Customer citizenship, Engagement involvement

The F-ratio in the ANOVA table tests whether the overall regression model is a good fit for the data. The result shows that customer citizenship and engagement involvement statistically significantly predict customer referrals, $F(4,298)=1323.776, \mathrm{p}(.000)<.05$ indicates that the regression model is a good fit of the data.

\section{(ii) Statistical Significance of the Independent Variables:}

Statistical significance of each of independent variables measures whether the nonstandardized (or standardized) coefficients were equal to 0 (zero) in the population (i.e. for each coefficient, $\mathrm{H} 0: \beta=0$ and $\mathrm{Ha}: \beta \neq 0$ ). If $\mathrm{p}<.05$, the coefficients are statistically significantly different from 0 (zero). The importance of these significant tests is to examine whether each test is valid.

\section{Table 5. Statistical Significance of the Independent Variables}

\begin{tabular}{|c|c|c|c|c|c|c|}
\hline \multicolumn{7}{|c|}{ Coefficients $^{a}$} \\
\hline \multirow[b]{2}{*}{ Model } & & \multicolumn{2}{|c|}{ Unstandardized Coefficients } & $\begin{array}{c}\text { Standardized } \\
\text { Coefficients }\end{array}$ & \multirow[b]{2}{*}{$t$} & \multirow[b]{2}{*}{ Sig. } \\
\hline & & $\mathrm{B}$ & Std. Error & Beta & & \\
\hline 1 & (Constant) & .276 & .143 & & 1.923 & .055 \\
\hline & Customer citizenship & .519 & .076 & .497 & 6.850 & .000 \\
\hline & Engagement involvement & .184 & .060 & .166 & 3.068 & .002 \\
\hline
\end{tabular}

a. Dependent Variable: Referrals 
Given that the t-value and corresponding p-value are in the "t" and "Sig." columns respectively, the tests revealed the following results: customer citizenship has beta value of 0.49 when $\mathrm{p}(.000)<0.05$; while engagement involvement has beta value of 0.166 when $\mathrm{p}(.002)<0.05$. This means that the predictor variables have a significant influence on referrals. Thus, a regression analysis was run to predict referrals from customer citizenship and engagement involvement. The model statistically significantly predicted referrals $F(4$, $298)=1323.776, p(.000)<.05$ indicates that the regression model is a good fit of the data. However, the two independent variables, customer citizenship $(.000)<0.05$; engagement involvement $\mathrm{P}(.002)>0.05$ added significantly to the prediction. The highest contributing predictor variable is customer citizenship (0.497) followed by engagement involvement which predict customer retention. This proves that value co-creation has a significant effect on customer retention in Aviation Industry in Nigeria.

A regression analysis was run on the effect of customer citizenship and engagement involvement on repeat purchase.

Table 6. Model Summary with respect to Repeat Purchase

Model Summary

\begin{tabular}{|c|c|c|c|c|c|c|c|c|c|}
\hline \multirow[b]{2}{*}{$\begin{array}{l}\text { Mod } \\
\text { el }\end{array}$} & \multirow[b]{2}{*}{$\mathrm{R}$} & \multirow[b]{2}{*}{$\begin{array}{c}\mathrm{R} \\
\text { Square }\end{array}$} & \multirow[b]{2}{*}{$\begin{array}{c}\text { Adjusted R } \\
\text { Square } \\
\end{array}$} & \multirow{2}{*}{$\begin{array}{l}\text { Std. Error } \\
\text { of the } \\
\text { Estimate }\end{array}$} & \multicolumn{5}{|c|}{ Change Statistics } \\
\hline & & & & & $\begin{array}{c}\text { R Square } \\
\text { Change }\end{array}$ & $\begin{array}{c}\mathrm{F} \\
\text { Change }\end{array}$ & df1 & df2 & $\begin{array}{l}\text { Sig. F } \\
\text { Change }\end{array}$ \\
\hline 1 & $.853^{\mathrm{a}}$ & .728 & .724 & .53391 & .728 & 456.337 & 4 & 298 & .000 \\
\hline
\end{tabular}

a. Predictors: (Constant), customer citizenship, engagement involvement

b. Dependent Variable: Repeat purchase.

The value of 0.853 indicates a good level of prediction. The "R Square" of 0.728 is the $R^{2}$ value which is the fraction of variance in the customer purchase that can be explained by customer citizenship and engagement involvement. Hence, from the result, approximately $27 \%(100 \%-73 \%)$ of the variation is caused by factors other than the predictors in this model. Thus, $73 \%$ proportion of variance in the repeat purchase can be explained by customer citizenship and engagement involvement.

\section{(i) Statistical Significance of the Model:}

Statistical significance of each of independent variables measures whether the nonstandardized (or standardized) coefficients were equal to 0 (zero) in the population (i.e. for each coefficient, $\mathrm{H} 0$ : $\beta=0$ and Ha: $\beta \neq 0$ ). If $p<.05$, the coefficients are statistically significantly different from 0 (zero). The importance of these significant tests is to examine whether each test is valid. 
Table 7. ANOVA Result

\begin{tabular}{|c|c|c|c|c|c|c|}
\hline \multicolumn{7}{|c|}{ ANOVA $^{a}$} \\
\hline \multicolumn{2}{|c|}{ Model } & Sum of Squares & $d f$ & Mean Square & $\mathrm{F}$ & Sig. \\
\hline \multirow[t]{3}{*}{1} & Regression & 263.410 & 4 & 1323.776 & 480.937 & $.000^{b}$ \\
\hline & Residual & 98.630 & 298 & 2.752 & & \\
\hline & Total & 362.040 & 302 & & & \\
\hline
\end{tabular}

a. Dependent Variable: Repeat purchase

b. Predictors: (Constant), customer citizenship, engagement involvement

The F-ratio in the ANOVA table tests whether the overall regression model is a good fit for the data. The result shows that customer citizenship and engagement involvement statistically significantly predict repeat purchase, $F(4,298)=1323.776, \mathrm{p}(.000)<.05$ indicates that the regression model is a good fit of the data.

\section{(ii) Statistical Significance of the Independent Variables:}

Statistical significance of each of independent variables measures whether the nonstandardized (or standardized) coefficients were equal to 0 (zero) in the population (i.e. for each coefficient, $\mathrm{H} 0: \beta=0$ and $\mathrm{Ha}: \beta \neq 0$ ). If $\mathrm{p}<.05$, the coefficients are statistically significantly different from 0 (zero). The importance of these significant tests is to examine whether each test is valid.

\section{Table 8. Statistical Significance of the Independent Variables}

\begin{tabular}{|c|c|c|c|c|c|c|}
\hline \multicolumn{7}{|c|}{ Coefficients $^{a}$} \\
\hline \multirow{2}{*}{\multicolumn{2}{|c|}{ Model }} & \multicolumn{2}{|c|}{ Unstandardized Coefficients } & \multirow{2}{*}{$\begin{array}{c}\text { Standardized } \\
\text { Coefficients } \\
\text { Beta }\end{array}$} & \multirow[b]{2}{*}{$\mathrm{t}$} & \multirow[b]{2}{*}{ Sig. } \\
\hline & & $\mathrm{B}$ & Std. Error & & & \\
\hline \multirow[t]{3}{*}{1} & (Constant) & .364 & .146 & & 1.823 & .035 \\
\hline & Customer citizenship & .602 & .077 & .594 & 6.720 & .000 \\
\hline & Engagement involvement & .174 & .072 & .356 & 3.268 & .000 \\
\hline
\end{tabular}

a. Dependent Variable: Repeat purchase

Given that the t-value and corresponding p-value are in the "t" and "Sig." columns respectively, the tests revealed the following results: customer citizenship $=p(.000)<0.05$; while engagement involvement $=p(.002)<0.05$. This means that the predictor variables have a significant influence on repeat purchase. Thus, a regression analysis was run to predict repeat purchase from customer citizenship and engagement involvement. The model statistically significantly predicted referrals $F(4,298)=1323.776, \mathrm{p}(.000)<.05$ indicates that the regression model is a good fit of the data. However, the two independent variables, customer citizenship $(.000)<0.05$ and engagement involvement $\mathrm{P}(.002)>0.05$ added significantly to the prediction. The highest contributing predictor variable is customer citizenship (0.594) followed by engagement involvement 0.356 which predict customer retention. This proves that value co-creation has a significant effect on customer retention in Aviation Industry in Nigeria. 


\section{Discussion of Findings}

It is expected that customer citizenship will enhance customer retention. This was supported in the hypotheses. Hence, the second tested hypotheses revealed a significant relationship between customer citizenship and customer retention. This was backed up by the work of (Groth, 2005), Rosenbaum and Massiah (2007) and Bettencourt (1997). Bettencourt (1997) relates to customer citizenship as customers' voluntary behaviors that serve as temporary employees and collaborate in activities that benefit a business with other others. Rosenbaum and Massiah (2007) disclosed that customer citizenship and customer retention work as voluntary action to promote a firm's interests. Citizenship manifested in variety of ways that it increases the growth and development of the services offered by the firm and exerts positive impacts on the efficiency of the company. Thus, the study asserts that customer citizenship will improve customer retention in Aviation Industry in Nigeria.

It is also expected that engagement involvement will enhance customer retention. This was supported in the hypothesis. Thus, from tested hypotheses, the study found that engagement involvement has a significant relationship with customer retention. This finding is backed up by the work of Anaza and Zhao (2013), Bienstock and Stafford (2006) and Zaichkowsky (1985). Anaza and Zhao (2013) found that engagement involvement entails the strategic involvement of customers and organizations in guiding the activities of a business transaction. Such strategic involvement of customers will lead to retention Zaichkowsky (1985) noted that involvement is the presumed significance of an entity to a person based on innate interests and beliefs. Engagement involvement is a fairly normal reaction dependent on the individual's experience. Despite several engagement involvements that marketing researches emphasized, the idea is that the extent to which the organization involves customers determines the retention level of customers. It is clear that the level of customer retention will be high if Aviation Industry in Nigeria will engage and involve customers.

\section{Conclusion}

The need for value co-creation in achieving customer satisfaction cannot be over emphasized. The study uncovered a significant relationship that exists between value co-creation and customer satisfaction in Aviation Industry in Nigeria. This implies that value co-creation affects customer satisfaction in Aviation Industry in Nigeria. It is concluded that customers engagement and customer citizenship are drivers of retention.

\section{Recommendations}

These are active recommendations made to improve customer satisfaction through value cocreation:

1. Management should retain customers who develop customer citizenship as this will increase customer retention in Aviation Industry in Nigeria

2. Management should pursue customer retention strategies by engaging and involving customers in strategic activities that will lead to quality business transaction to increase emotive commitment in Aviation Industry in Nigeria. 


\section{Implications of the study}

The study is centered on value co-creation and customer retention in Aviation Industry in Nigeria. No customer will continue with a particular industry in which no value is found. The existence of the Aviation Industry is to maximize profits from their operations as they create value that meets customers' expectations. The findings from our analyses clearly show that Aviation Industry in Nigeria cannot achieve its goals without the actual value co-creation with customers. We understand that many customers preferred road transportation to Air travel perhaps due to price rates and lack of engaging customers and at the same time involving them in creating values to meet their expectations. Practically, the study unveiled the truth behind co-creating values with customers for symbiotic survival of the Aviation Industry and the customers and to make up a good business relationship. The claim by this study really shows that customer would be retained if engaged and involved in value cocreation processes since the services created are for them.

\section{Contributions to Knowledge}

The study made strong contributions to streams of research studies on the construct in literature. The study developed conceptual framework which helps in drawing valid conclusion on how value co-creation affects customer retention thereby enhances knowledge on these concepts in literature. The two dimensions of value co-creation provide a solid foundation for better treatment of the effect of value co-creation on customer retention in literature.

\section{Areas for Further Research}

The challenges associated with value co-creation and how to increase customer retention might have affected the goal achievement in these sectors. Again, how to retain customers is a big challenge in Aviation Industry because retention indicates that customers can continue repeat purchase, make referrals and become a member of the business (stakeholders) so that the organization will experience fast growth. Therefore, further research is needed in this sector. Research on these concepts in the tourism sector might seem unimportant to some since they are not operating like the Aviation industry. However, there are values found in this sector by customers. These values could be identified in beautiful infrastructures, recreational facilities, museums, libraries, cultural displays and Parks which occasionally attract customers' attentions. Customers may find values in these areas and their retention might depend on how well the values meet their expectations because a situation where values are created and does not satisfy customers is a waste of material and no-material resources. Hence, a research study could be carried out on 'Value Co-creation and Customer Loyalty in tourism firms in Nigeria. 


\section{References}

Ammari, N.B. \& Jaziri, E. (2016).How Co-creating Enhances the Quality of a Brandconsumer Relationship, using the U\&G Approach: The Coca-Cola Case. Journalof Marketing Research and Case Studies, https://doi.org/10.5171/2016.609295

Anaza, N.A. \& Zhao, F. (2013). Encounter-based antecedents of e-customer citizenship behaviors. Journal of Services Marketing, 27(2), 130-140. https:/doi.org/10.1108/08876041311309252.

Andrews, J. Durvasula, C. Akhter, S. \& Syed H. A. (1990). Framework for Conceptualizing and Measuring the Involvement Construct. Journal of Advertising, 19, 4-2

Ang, L. \& Buttle, F. (2006). Customer retention management processes - a quantitative study. European Journal of Marketing, 40(1/2), 83-99.

Baridam, D. M. (2001). Research methods in administrative sciences ( $3^{\text {rd }}$ eds)Sherbrooke Associates.

Bettencourt, L .A. (1997). Customer voluntary performance: customers as partners in service delivery. Journal of Retailing, 73(3), 383-406.

Bienstock, C. C. \& Stafford, M. R. (2006). Measuring involvement with the service: a further investigation of scale validity and dimensionality. Journal of Marketing Theory and Practice, 24(2), 2-6.

Bove, L. L., Pervan, S. J., Beatty, S. E., \& Shiu, E., (2009). Service worker role in encouraging customer organizational citizenship behaviors. Journal of Business Research, 62, 698-705.

Bowley, A. L. (1964). Measurements of precision attained in sampling. Bulletin. International Statistics Institutions. Amsterdam, 22, 1-62.

Buttle, F. (2008). SERVQUAL: review, critique, research agenda. European Journal of Marketing, 30(1), 8-32.

Coviello, N. E; Brodie, R. J. B., Danaher, P. J. \& Wesley J .J. (2002). How firms relate to their markets: An empirical examination of contemporary marketing practices. Journal of Marketing,66(3), 33-46.

Cronbach, L. J. (1951). Coefficient alpha and the internal structure of tests. Psychometrika, 16(3), 297-334.

Duguid, P. (2005). The Art of Knowing': Social and Tacit Dimensions of Knowledge and the Limits of the Community of Practice. Informational Social, 21, 109-118. https:/doi.org10.1080/01972240590925311.

Egan, J. (2004). Relationship marketing: exploring relational strategies in marketing. Second edition. Edinburgh, Pearson education. 
Erriksson, K. \& Vaghull, A. L. (2000). Customer Retention, Purchasing Behavior and Relationship Substance in Professional Services. Industrial Marketing Management, 29(4), 363-372

Frow, P. \& Payne, A. (2013). Co-creation: a typology and framework', Working Paper, Discipline of Marketing.

Frow, P., Nenonen, S. Adrian Payne, A. \&Storbacka, K. (2015). Managing Co-creation Design: A Strategic Approach to Innovation. British Journal of Management, 26(3), $2-8$.

Grönroos, C. (2000). Service management and marketing: a customer relationship management approach. John Wiley \& Sons.

Grönroos, C. (2008). The Relationship Marketing Process: Communication, Interaction, Dialogue and Value. Journal of Business \& Industrial Marketing, 19(2), 99-113.

Groth, M. (2005). Customers as Good Soldiers: Examining Citizenship Behaviors in Internet Service Deliveries. Journal of Management, 31(1), 7-27

Gupta, S. \& Lehmann, D.R. (2003). Customers as Assets. Journal of Interactive Marketing $17(1), 9-24$.

Jolson, M. (1997). The salesman's career cycle. Journal of Personal selling and sales management (fall), 75-88.

Jones, T.O. \& Sasser, W.E. (1995). Why Satisfied Customers defect. Harvard Business Review, 88-99.

Kau, A.K., \& Loh, E.W. (2006). The effects of service recovery on consumer satisfaction: A comparison between complainants and non-complainants. The Journal of Services Marketing, 20(2), 101-111.

Kotler, P. \& Keller, K. L. (2009). Marketing management (13th ed.): Pearson Prentice Hall.

Maduka, O.B. (2016). Effects of Customer Value Co-Creation on Customer Loyalty in the Nigerian Service Industry International Journal of Business Management, 11(12), 28.

Nirmali, A., Yajid, M.S. \& Azam, F. (2001). Value co-creation and organizational performance in Malaysia, 3-7.

Oliver, R. L. (2006). Customer satisfaction research: In Handbook of Marketing Research ed. Pajiv Grover and Marco Viens. Thousand Oaks, C.A. Sege Publications, 56987.

Orlikowski, W. J. (2007). Sociomaterial practices: Exploring technology at work. Organization studies, 28(9), 1435-1448

Prahalad, C.K. \& Ramaswamy, V. (2004). Co-production and customer loyalty in financial services. Journal of Retailing,3(3), 359-370. 
Journal DOI: www.doi.org/10.46654/ij.24889849

\section{Article DOI: www.doi.org/10.46654/ij.24889849.s7314}

Ramakrishnan, M. (2006). The Value Profit Chain;Treat Employees Like Customers and Customers like Employees: The Free Press.

Ramaswamy, V. \& K. Ozcan (2014). The Co-Creation Paradigm. CA: Stanford University Press.

Ramaswamy, V., \& Gouillart, F. (2010). The Power of Co-creation.: The Free Press.

Reckwitz, A. (2002), 'Towards a theory of social practices', European Journal of Social Theory, 5 (2), 243-263.

Reichheld, F. F. (1996). Learnig from customer defections. Harvard Business Review, 74(2), 56- 67.

Reichheld, F. F., \& Sasser Jr., W. E. (1989). Zero defections: Quality comes to services. Harvard Business Review, 68(5), 105-111.

Reichheld, F. F., Markey Jr., R. G., \& Hopton, C. (2000). The loyalty effect-the relationship between loyalty and profits. European Business Journal, 12(3), 134-139.

Reichheld, F. F., Teal, T., \& Smith, D. K. (1996). The loyalty effect. Boston: Harvard Business School Press.

Sathish, M., Kumar, K. S., Naveen, K. J., \& Jeevanantham, V. (2011). A study on consumer switching behaviour in cellular service provider: A study with reference to Chennai. Far East Journal of Psychology and Business, 2(2), 71-81

Rosenbaum, M.S. \& Massiah, C. (2007). When Customers Receive Support From Other Customers: Exploring the Influence of Inter-customer Social Support on Customer Voluntary Performance. Journal of Service Research, 9(3), 257-270

Schatzki, T. R. (2006). On organizations as they happen. Organization Studies, 27, 18631873

Smith, C.N., Organ, D.\& Near, J.P. (1983). Organizational citizenship behavior: Its nature \& antecedents. Journal of Applied Psychology,68(4), 653-663 .

Song, J. H. \& Carl, R. A. (1993). Differentiation Through Customer Involvement in Production or Delivery. Journal of Consumer Marketing,10(2), 4-12.

Spector, P. (2008). Industrial and organizational psychology: Research and practice (5th ed. John Wiley \& Sons.

Spreng, A. R., Harrell, G. \& Mackoy, D. R. (1995). Service recovery: Impact on satisfaction and recovery, Journal of Services Marketing, 9(1), 15-23.

Srinivasan, S, \&Westervelt, E. (2009). A low-dimensional sagittal-plane forward-dynamic model for asymmetric gait and its Application to Study the Gait of Transtibial Prosthesis Users

Vilares, E., Kell, C. \& Voima, P. (2001). Satisfying customers need. Journal of Academic 
Marketing Science,4(1), 133-150.

Warde, A. (2005). Consumption and theories of practice. Journal of Consumer Culture, 5(2), 131- 153 .

Yamane, T. (1967). Statistics: An Introductory Analysis, 2nd Ed. Harper and Row.

Yi, T. \& Gong, F.S. (2013). Lost in CO-X, Proceedings from IASDR2011; the 4th World Conference on Design Research.

Yi, Y., Nataraajan, R., \& Gong, T., (2011). Customer participation and citizenship behavioural influences on employee performance, satisfaction, commitment, and turnover intention. Journal of Business Research, 64(1), 87-95.

Zaichkowsky, P. (1985). Co-creating unique value with customers. Strategic Leadership, 3(2), 3-9. 